\title{
Os povos indígenas e o Covid-19
}

Estado da arte e revisão da literatura

\section{Paul Codjia e Raphaël Colliaux}

\section{(2) OpenEdition} Journals

Edição electrónica

URL: https://journals.openedition.org/jsa/19804

DOI: 10.4000/jsa. 19804

ISSN: 1957-7842

Este artigo é uma tradução de:

Les Amérindiens face au Covid-19 - URL : https://journals.openedition.org/jsa/19674 [fr]

Outra(s) tradução(ões) deste artigo:

Amerindians in the face of Covid-19 - URL : https://journals.openedition.org/jsa/19797 [en] Los Amerindios frente al Covid-19 - URL : https://journals.openedition.org/jsa/19799 [fr]

\section{Editora}

Société des américanistes

\section{Edição impressa}

Data de publição: 30 setembro 2021

Paginação: 329-334

ISSN: 0037-9174

\section{Refêrencia eletrónica}

Paul Codjia et Raphaël Colliaux, "Os povos indígenas e o Covid-19 », Journal de la Société des américanistes [En ligne], 107-1 | 2021, mis en ligne le 30 septembre 2021, consulté le 03 septembre 2022. URL : http://journals.openedition.org/jsa/19804; DOl : https://doi.org/10.4000/jsa. 19804

Este documento foi criado de forma automática no dia 3 setembro 2022.

Tous droits réservés 


\title{
Os povos indígenas e o Covid-19
}

\author{
Estado da arte e revisão da literatura
}

\section{Paul Codjia e Raphaël Colliaux}

Este texto é uma breve apresentação de uma lista de referências em construção que reúne trabalhos on-line de diversos tipos (textos científicos, artigos de jornal, vídeos, fotos) sobre as condições de vida dos ameríndios durante a atual crise sanitária mundial. Tal lista, organizada em diferentes seções, é acessível no website da Société des américanistes (www.americanistes.org), que inaugura uma rubrica inteiramente dedicada a esta questão. Se os coordenadores deste trabalho se concentraram inicialmente na bacia amazônica em razão de suas afinidades particulares com a região, a lista de referências reunirá também textos e outros materiais que descrevem a situação dos ameríndios de outras partes do continente americano em tempos de pandemia. 
Fig. 1 - A doença do Covid-19, Jaime Diakara'

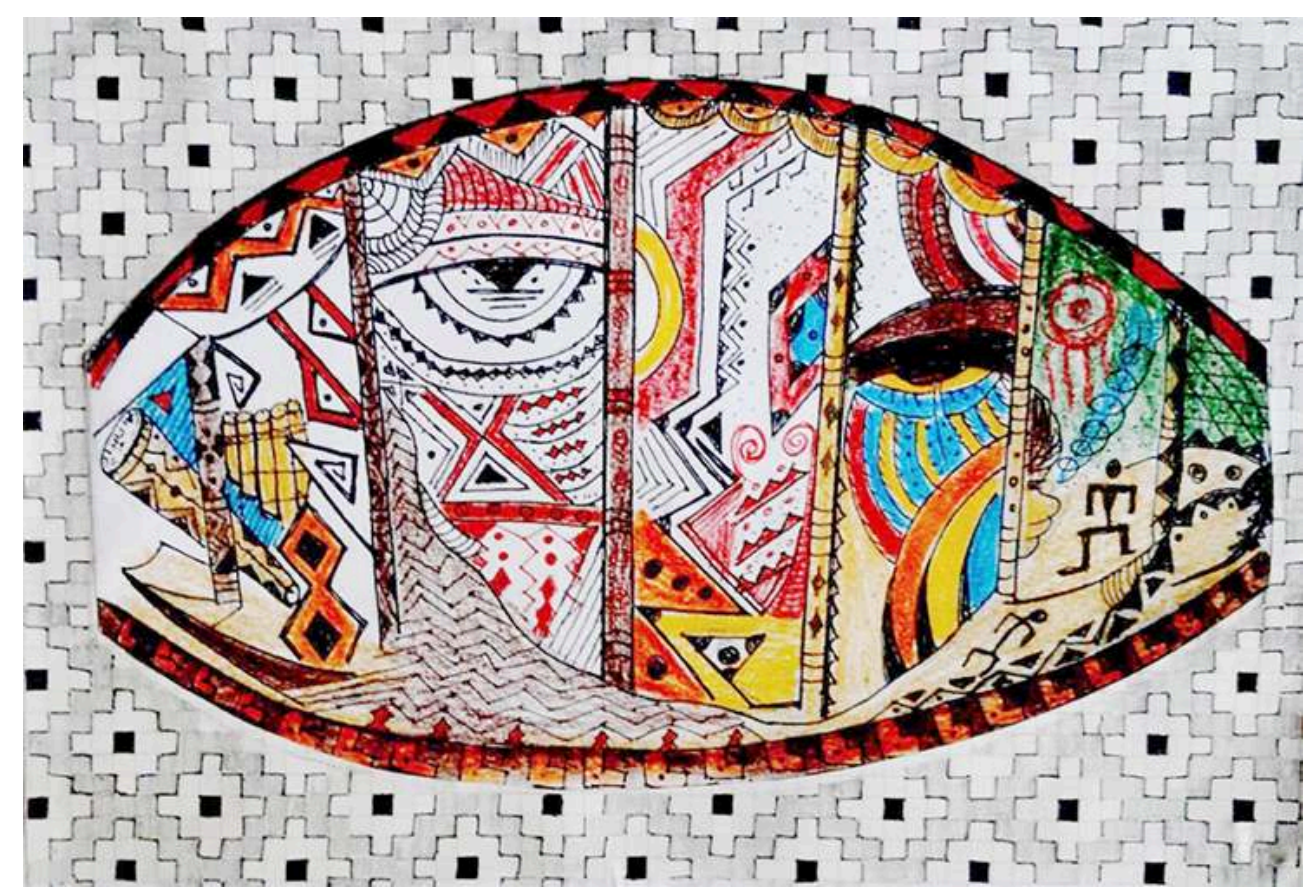

$* * *$

2 Desde abril e maio de 2020, diversos intelectuais, jornalistas, líderes políticos ameríndios e membros de ONGs têm se dedicado a documentar o impacto da pandemia do Covid-19 nas populações indígenas da bacia amazônica. Seja na forma de artigos, de postagens em blogs científicos, ou ainda em jornais da grande mídia, todos esses textos alertam, cada um à sua maneira, sobre as consequências sanitárias, sociais, econômicas, ecológicas, políticas e antropológicas da propagação do SARS-CoV-2 nas terras baixas da América do Sul. É importante, aqui, reconhecer a reatividade e os esforços que já foram feitos não apenas para promover a conscientização, mas também para produzir análises e reflexões em tempo recorde e com o objetivo de tornar visível a situação dramática em que essas populações muitas vezes se encontram. Em diversos casos, a pandemia se somou a contextos de precariedade territorial, de sistemas de saúde ineficazes e de políticas públicas não raro desfavoráveis aos direitos indígenas. O caso do Brasil e do regime bolsonarista é, sem dúvida, o exemplo mais trágico.

Reunimos nessa lista não exaustiva de referências vários textos que oferecem um panorama abrangente da diversidade de situações e de dificuldades que os povos amazônicos enfrentam em tempos de Covid-19. O objetivo dessa compilação é permitir que o leitor identifique problemáticas, abra perspectivas de pesquisa e continue o trabalho de documentação, publicização e apoio aos povos indígenas das Terras Baixas da América do Sul. Forçados a ficar atrás das telas de seus computadores para não se transformarem em vetores da doença, um grande número de pesquisadores especializados nessa região se contenta agora com trocas esporádicas com seus interlocutores e amigos no campo e com a coleta de informações dispersas nas redes sociais ou na mídia. Assim, a presente lista visa facilitar as investigações - e é por isso que um estado da arte da literatura científica sobre o Covid-19 na Amazônia é apresentado ao lado de artigos de imprensa e de materiais não analisados, como uma 
coleção de links contendo diretrizes sanitárias traduzidas para os idiomas ameríndios. Desta forma, apresentamos primeiro artigos científicos e números especiais e, em seguida, reunimos, nas diferentes rubricas e em função da temática que abordam, artigos de jornal.

4 Vale ressaltar que, nesse período de isolamento, não são apenas os pesquisadores não indígenas que colocam em questão as metodologias da pesquisa etnográfica, pois este é um resultado inevitável da própria situação de pandemia. Nesse sentido, talvez esta seja uma lição importante a retirar do levantamento bibliográfico ainda incompleto: o contexto sanitário parece acelerar a colaboração nas análises - e até mesmo no trabalho de escrita - entre pesquisadores e representantes dos povos indígenas. Além disso, um número significativo de artigos vem sendo escrito por intelectuais indígenas, vindos principalmente da Amazônia brasileira. Apesar dos confinamentos, os meios de comunicação permitem um trabalho constante de vigília e coleta de informações (é o caso, por exemplo, de páginas Facebook como https://www.facebook.com/groups/ coronamazon/, administrada por Émilie Stoll e moderada por Ricardo Folhes e Élise Capredon), além de trocas e reflexões conjuntas com os contatos indígenas locais, geralmente líderes políticos.

5 Em termos de conteúdo, além de descrições estatísticas da situação epidemiológica, os artigos lançam reflexões gerais sobre vários eixos de trabalho que resumimos no que segue. Antes de mais nada, a temática central presente em praticamente todos os textos é aquela da relação entre os povos indígenas, os Estados e seus sistemas de saúde. Os textos sublinham a incapacidade estatal de responder às necessidades sanitárias dos povos indígenas. Isto ocorreria em razão de políticas de saúde desiguais, mas também - e talvez de maneira mais grave - por conta do desconhecimento das realidades sociais no que diz respeito, por exemplo, à infraestrutura local e às práticas ameríndias relativas à saúde. As palavras empregadas pelos interlocutores indígenas para descrever essa situação são impactantes. Elas oscilam entre o campo semântico do abandono - principalmente nos países andinos - e aquele da ausência - especialmente no lado brasileiro, onde os povos indígenas já não guardam nenhuma ilusão quanto às intenções hostis do regime Bolsonaro em relação a eles. $\mathrm{Na}$ ausência de recursos institucionais eficazes para proteger seus corpos, os ameríndios optam pela proteção de seus territórios.

6 Notamos, assim, uma clara reafirmação das reivindicações de soberania territorial soberania esta, diga-se de passagem, paradoxalmente reforçada pelas recomendações dos Estados andinos no sentido de incentivar os povos ameríndios a fechar e controlar o acesso a seus territórios. Como notou Irène Bellier em diferentes comunicações mencionadas abaixo, há uma estreita ligação, de natureza principalmente alimentar, entre a saúde das pessoas e a saúde de seus territórios. Nesse sentido, recorre-se constantemente à ideia de que uma alimentação produzida nos territórios indígenas seria uma das condições para a manutenção de uma boa saúde, ao contrário da alimentação proveniente das cidades inicialmente atingidas pelo Coronavírus. Esse desejo de proteção do território se manifesta em particular nas lutas organizadas para frear as atividades garimpeiras ou madeireiras. Assim - e talvez com certa ironia - o coordenador da Coordinadora de Organizaciones Indígenas de la Cuenca Amazónica (COICA), Gregorio Mirabal, afirmou recentemente: "Tenemos que hacer un proceso de vacunaciones en todos los territorios de la cuenca amazónica con esa vacuna que se llama gobernanza territorial indígena y que es lo único que nos puede salvar." (“Temos de levar a cabo um processo de vacinação em todos os territórios da bacia amazónica com essa 
vacina que se chama 'governação territorial indígena', e que é a única coisa que nos pode salvar.")

7 Além disso, nos impressionamos com o fato de que a ausência do Estado causou o aumento de demandas por território e por autonomia entre os ameríndios. Ao mesmo tempo, percebemos que os indígenas se viram em face de uma retomada atroz das atividades extrativas - como, por exemplo, as extrações minerais, de madeira e de combustíveis fósseis. No Peru, desde maio de 2020, uma série de decretos exonerou certos setores econômicos das normas ambientais restritivas e relaxou os mecanismos de consulta prévia necessários ao desenvolvimento de projetos extrativistas. Potencialmente, a pandemia pressagia, assim, um duplo movimento: por um lado, de retração do poder público e, de outro, de ressurgimento de um setor privado multifacetado e cujas atividades são muitas vezes informais e até mesmo criminosas. 0 assassinato de líderes ameríndios e de ativistas ambientais que se multiplicaram depois do começo da pandemia (principalmente na Amazônia peruana e colombiana) nos lembram, de maneira trágica, que os territórios indígenas são mais do que nunca objetos de cobiça.

8 Contudo, a aceitação ou não dessas atividades nos territórios ameríndios também é objeto de debate entre as próprias populações indígenas, visto que a crise sanitária muitas vezes abalou diretamente a entrada de recursos financeiros nas comunidades. Como vemos, a pandemia exacerba problemáticas antigas, em que a ação dos missionários protestantes na região é outro caso exemplar: diversas fontes sugerem que os pastores evangélicos aproveitaram o medo suscitado pelo vírus para consolidar ainda mais sua influência e dar novo ânimo às suas ambições proselitistas.

9 Se as intenções dos missionários multiplicam as inquietudes, é preocupante o caso dos grupos ameríndios em situação de isolamento voluntário com os quais alguns setores religiosos estariam dispostos a forçar o contato - o que, diga-se de passagem, se deve a uma profunda reconfiguração das dinâmicas políticas locais que apenas começamos a conhecer. $\mathrm{Na}$ verdade, desde pelo menos o século $\mathrm{XVI}$, as populações ameríndias da Amazônia desenvolveram estratégias de distanciamento para se proteger das ameaças imunológicas (varíola, catapora, gripes) relacionadas em particular à colonização europeia, mas possivelmente também resultado de zoonoses potencialmente presentes na floresta tropical (ver artigo de Stephen Rostain ${ }^{2}$ ). Em muitos casos, esse desejo de isolamento voluntário se intensificou ao longo dos anos à medida que novas formas de colonização apareciam e se intensificavam (proselitismo evangélico e católico, agronegócio, exploração de combustíveis fósseis, garimpo, extração ilegal de madeira, narcotráfico, turismo) em face das quais as instituições públicas locais se mostraram impotentes ou até mesmo condescendentes. Se, em razão de seu isolamento anterior, esses ameríndios continuam extremamente vulneráveis às doenças infecciosas e virais, $\mathrm{o}$ Covid-19 constitui para eles um perigo considerável que muitos observadores se dedicam a documentar.

10 O tema fornece, além disso, matéria de reflexão de grande envergadura sobre a noção de "isolamento social". Os dias atuais, a bem dizer, têm o mérito de inverter a percepção dessa prática como reflexo primitivo e anacrônico de ameríndios hostis à modernidade. Pelo contrário, as medidas mundiais tomadas contra o Covid-19 revelam, por seu efeito de espelho, em que medida esses modos de vida ameríndios emergem diretamente do contexto social e político (logo, viral) com o qual essas populações foram confrontadas, 
justificando assim seu desejo de um isolamento social protecionista partilhado, agora, com os próprios Estados nacionais.

11 Por fim, esses textos não se contentam em apresentar panoramas sombrios da situação. Eles sublinham também os formidáveis recursos logísticos, políticos e sanitários que os indígenas mobilizaram para se proteger, enfrentar e buscar interromper as dinâmicas de transmissão do vírus. Diversas iniciativas indígenas surgiram para valorizar seus saberes e suas práticas medicinais locais e para reivindicar uma verdadeira interculturalidade nas políticas sanitárias estatais.

A epidemia aparece assim como um "fato social total" em contexto pós-colonial, um nó no qual entram em atrito até mesmo práticas do luto e considerações escatológicas divergentes. Bruce Albert alerta, nesse sentido, para a tragédia vivida pelos Yanomami privados dos corpos de seus parentes doentes que, após falecerem, foram cremados pelos serviços sanitários a fim de evitar novos contágios. A lista de referências revela, então, uma "situação epidêmica" - para parafrasear Georges Balandier - que coloca mais do que nunca em relação o conjunto dos atores locais: diferentes populações ameríndias sedentarizadas, colonos, empresas privadas, instituições públicas, bem como, evidentemente, o vírus. ${ }^{3}$

\section{Lista de referências disponível no site da Société des américanistes}

http://www.americanistes.org/pt/2021/06/27/os-povos-indigenas-e-o-covid-19-estadoda-arte-e-revisao-da-literatura/

\section{Sumário das rubricas}
1. Trabalhos científicos
2. Crônicas ameríndias
3. Práticas terapêuticas indígenas
4. Indígenas em contexto urbano e o Coronavírus
5. Atividades extrativas e pandemia
6. Missionários evangélicos
7. Populações ameríndias em isolamento voluntário
8. Foto-reportagens e outras imagens
9. Informações institucionais
10. Orientações preventivas em línguas indígenas 


\section{NOTAS}

1. Jaime Diakara é antropólogo e pintor Desana (um grupo da família linguística tukano, Amazônia Brasileira). $O$ autor criou esta obra depois de ter sido afetado pela doença. Queria expressar os sintomas que tinha experimentado. Ele explica que a parte esquerda representa a contaminação pela SRA-CoV-2 e como o vírus tomou posse do seu corpo. $O$ lado direito mostra as figuras do seu pai e antepassados que, com seus conhecimentos ancestrais sobre plantas medicinais, o ajudaram a vencer o vírus.

2. "Amazonie, une histoire sans geste barrière " [em linha], 16 de Dezembro de 2020 https://covidam.institutdesameriques.fr/amazonie-une-histoire-sans-geste-barriere/, consultado em 25/05/2021.

3. Traduzido por Maria Luísa Lucas.

\section{AUTORES}

PAUL CODJIA

McGill University - Fondation Fyssen - IFEA, membro do projeto Amaz (ANR-17-CE41-0013)

RAPHAËL COLLIAUX

IFEA - PUCP - Fondation Fyssen, membro do projeto Amaz (ANR-17-CE41-0013) 